\title{
Flipping theClassroom; Developing listening Material
}

\author{
JennyIkaMisela \\ University of Nusantara PGRI Kediri \\ E-mail Address: jennyikamisela@gmail.com
}

\begin{abstract}
Abtract
Flipped classroom is an approach to teach listening in which students participate in online learning in place of traditional homework and then attend school for face-to-face, teacher-guided practice or projects. It is a part of larger education system called blended learning. In this approach, students could learn new content on their own by watching video lectures or other online sources and assigned problems (traditional "homework") are completed in class with teachers offering personalized guidance instead of lectures. The paper here examined an ESL listening class. Listening skill is much more than hearing. Unfortunately, in students' opinion, listening is an uninteresting activity. Many students feel very bored in listening class. That is why teachers should know about how to make the students more interested in listening. The aim of this paper is discuss best practices and challenges of implementing the flipped classroom in teaching and learning listening. By using this approach, it is expected that students will develop their listening skills as well as have a lot of fun. The main findings of the study indicate that the students enjoyed learning listening in a flipped classroom environment. They can practice not only listening but also all language skills in listening class.
\end{abstract}

Key Words:flipped classroom, listening, blended learning, e-learning,

\section{Introduction}

Listening is very important one but difficult to improve. To be able to listen well,one must do much more than hearing. Unfortunately, many students feel unsuccessful in listening class. From the need analysis conducted in the University of Nusantara PGRI Kediri, more than $90 \%$ of the first semester students of English Department felt boring during listening class. There are many reasons from them, but generally they said that listening is an uninteresting activity. The next problem is that the quality of sounds is bad. It makes the students not able to hear the voice 
| Volume: 1 | Number: 1 | February 2016 | ISSN:

well. Third, the students are unfocused and have less concentration while listening. That is why teachers should know about how to make the students more interested in listening process. Teachers should choose the right media so they will enjoy learning.

According to Harmer (2001: 228), “students can improve their listening skills-and gain valuable language input-through a combination of extensive and intensive listening material and procedures". Based on statement above it can be concluded that the ideal teaching listening is by combining listening in classroom and outside.

Traditional learning typically occurred in a teacher-directed environment with person-to-person interaction in a live synchronous, high fidelity environment. On the other hand, distance-learning systems emphasized self-paced learning and learning-materials interactions that typically occurred in an asynchronous, low fidelity (text only) environment. To bridge the two systems of education, the educators then develop one more type of learning, it is called Blended learning.

Blended learning is a formal education program in which a student learns at least in part through online delivery of content and instruction with some element of student control over time, place, path or pace. While still attending a "brick-andmortar" school structure, face-to-face classroom methods are combined with computer-mediated activities. Proponents of blending learning cite the opportunity for data collection and customization of instruction and assessment as two major benefits of this approach. Schools with blended learning models may also choose to reallocate resources to boost student achievement outcomes.

Based on the explanation above, the researcher is interested to develop an English materials using blended learning with flipped classrom approach. The material which to be develop here is limited to listening subject for the first year students of English Department in University of Nusantara PGRI Kediri. The materials will consist of severals items that uploaded and discussed on line, using Edmodo as its virtual classroom, and some others items are conducted in the classroom with face to face traditional ways.

Rost (2002:2) there are four orientations provided through the definitions of listening, they are receptive, constructive, collaborative, and transformative. 
Receptive orientation defines listening receiving information from other speakers accurately according to what he originally says.Constructive orientation define listening as a meaning of negotiation with the speaker, and as mean of response. While transformative orientation defines listening as the meaning of creation though involvement, imagination, and empathy. To be active listener students need to take an active role in constructing meaning with the speakers. Effective listening will involve attention to the social interaction, as that is where conversational meaning is monitored and negotiated. The notion of involvement, engagement, and negotiation are related to pragmatic approach to listening. The pragmatic point of view is that the attention of listening is to complete the process of communication, so the engagement is needed in which the listeners switch from becoming a presence to an interpreter. From the nature of listening description above can be described that listening is vital in language classroom because it provides input for students.

According to Brown, "Listening is so challenging, teachers need to think carefully about making our activities successful and our content interesting", (2006:1). Based on statement above the researcher concludes that the teachers role is make the listening process become more interesting activity for the students. So the students will have more motivation in participating of listening class.

Flipped classroom is a course or subject in which students participate in online learning off-site in place of traditional homework and then attend the brickand-mortar school for face-to-face, teacher-guided practice or projects. The primary delivery of content and instruction is online, which differentiates a Flipped Classroom from students who are merely doing homework practice online at night. Here, the researcher used Edmodo as the virtual class to discuss and practice the material online. A flipped classroom (also known as flip teaching and the Thayer Method) is a learning environment where students learn new content on their own by watching video lectures or other online sources and assigned problems (traditional "homework") are completed in class with teachers offering personalized guidance instead of lectures. Essentially the classroom has been 
| Volume: 1 | Number: 1 | February 2016 | ISSN:

flipped from a traditional learning environment. The benefits of using flipped classroom are it:

- allows students to learn on their own time and at their own pace. This allows you to give them more one-on-one instruction as well as give your students the opportunity to ask questions about the subject matter that they find confusing or difficult.

- allows students to have more time for collaborating with other students which can be a great learning experience for the students and as a way for them to build their teamwork abilities.

- When a student is watching a video lecture, for instance, the lecture is free of interruptions to distract the students and can be replayed as often as the student would like. This extends to when a student is preparing for an exam as they can go back and review previous lectures.

- After students engage with a digital lesson or watch a video at home, they can brainstorm questions to ask you which can open the floor for a discussion about anything that may have been unclear or confusing. Coming to class prepared with ideas and questions is a great way to jumpstart the class and share ideas between students.

- Sick days will no longer interrupt a student's ability to learn. With a flipped classroom, students engage with a lesson on their own time and an absence will not detract from them learning the material. On the same note, when you are absent from school, your students will not suffer from a substitute's inability to teach your lesson. The substitute only needs to oversee students working on their assignments in the classroom and be able to answer questions instead of introducing new content.

- Often times, multiple teachers are teaching the same course. If you have all created a flipped classroom, you can give students access to different teachers' digital content and videos in order to increase their comprehension of the subject matter. By allowing students to have access to multiple styles of teaching, this will increase their comprehension of the subject. 


\section{Method}

The major steps to develop listening material using blended learning method with flipped classroom approach include research and information collecting, developing the material for teaching and learning, Try Out the material, and revising the material that already develop. This includes reviews of literature about language learning theories in relation to blended learning and the use of computer as a media for teaching and learning languages. Questionnaires will be developed to obtain information from the respondents (Arikunto, 2002). The number of respondents was 40 students and was representative, meaning that all features and characteristics present in the total respondents. The first questionnaire is intended to support the interview and observation about how the blended learning method for the teaching and learning English to support the learning and teaching process. The second questionnaire is developed to find the learners' response toward the blended learning method for teaching and learning Listening subject. This will cover the students' opinion on (1) learning by using Edmodo as media for virtual class in teaching and learning Listening subject; (2) learning activities in the blended learning method; (3) benefits obtained from learning material presented in the classical class and virtual class. The third questionnaire is developed to find out the response toward the blended learning method for teaching learning Listening, this explores the opinion on (1) content of the blended learning method for teaching learning Listening (teaching and learning materials); (2) mode and instructions used in blended learning method for TEFL; (3) benefit of the materials and presentation of blended learning method for TEFL. The next step developing the listening material with blended learning method, A teaching and learning for listening materials for the model written and uploaded at the Learning Management System site (using modified Edmodo 2.3 platform). Some of the material for virtual class must be converted into digital file, so Edmodo 2.3 will read and provided it in the browser. Some others are given in the classical class which requires face-to-face evaluation. The evaluation device such as questionnaires and interview guidelines are prepared in the form of book. To obtain an appropriate model for teaching and learning Listening in English Department of Nusantara PGRI Kediri University, a trial stage has been conducted. 
| Volume: 1 | Number: 1 | February 2016 | ISSN:

Data obtained from this trial stage will be used as a material evaluation and development to get the appropriate Listening material with blended learning method.The listening material with flipped classrom, in the form of students book, is revised after doing the try out, validating the data, analizing the quissionaire and getting some suggestions from the expert. By doing so, it is expected that the material could be more beneficial and appropriate for the students

\section{Discussion}

The text book evaluation result showed that the book indeed used a flip classroom approach. It show from the instructions in each exercise, they are some exercises that done in the class offline and on the virtual class online using Edmodo as its LMS (Learning Media System). For the exercise given instruction "Flip your listening" the students must do the exercise online. The other signed "In the classroom" means they have to do it the the classroom offline, face to face with the lecturer and the other students. The flip classroom is one of the approach under the term of blended learning.

Some experts have given their opinions and suggestion to make the material more appropriate to meet the students' need. After tryout, the expert then gave some more comments to revise the book. The first expert main suggestion was to correct some grammar in the instruction of exercise in page $2,8,12,14,19,25$, and 35.

The second expert in listening material suggested to change some pictures with more polite ones since Indonesian are rather strict with choosing the appropriate clothes. She also suggested to change the exercise into more enganging with Indonesian culture by replacing the currency used in the exercises with Indonesia currency.

The third expert said that the video uploaded in the edmodo are too large so it needs more time to download it or to watch it online. It's better if the researcher upload the video on youtube or daily motion to make it easier for students to access the video. The third expert said that edmodo has various kind of tools to make exercises, quizzes or kind of assignments that can be used to make the

94| ENGLISH-EDU

Journal of English Teaching and Research 
assignment or exercise in the book more interesting and enganging to the students. So it is not monoton.

\section{Conclusion and Suggestion}

\section{Conclusion}

The advantages of listening material with flipped classroom approach based on the lecturer point of view are (1) the materials are provided with Indonesian culture and with some recording that use Indonesian accent, so it is easier for the lecturer to give the authentic example for each material (2) Using edmodo as the virtual class, the lecturer can give the material to the students before they meet in the classroom so it save a lot of time (3) the material which is uploaded in the virtual class can be accessed anywhere and anytime, the lecturer can give the score in more flexible time and place (4) Because some materials is done in online, so students will get the more opportunity to improve their listening skill which cannot get in the classroom (5) lecturer can handle post, quiz, assessment and forum discussion and share with students in real time. The weakness point about conducting the online class room based on the lecturer. (1) sometimes it is hard to convert the video file which is used in the brain storming because of the limit of file size uploaded (only $2 \mathrm{Mb}$ ), (3) it is rather difficult if the lectuer wants to inteact with the students online because there is no chat room for live communication between the lecturer and students, so the lecturer left comment on the students assignment.

The advantages of listening material with flipped classroom approach based on the students point of view are (1) It allows students to learn on their own time and at their own pace, (2) It allows students to have more time for collaborating with other students which can be a great learning experience for the students and as a way for them to build their teamwork abilities (3)When a student is watching a video lecture, it is free from interruptions to distract the students and can be replayed as often as the student would like (4) After students engage with a digital lesson or watch a video at home, they can brainstorm questions to ask you which can open the floor for a discussion about anything that may have been unclear or 
| Volume: 1 | Number: 1 | February 2016 | ISSN:

confusing. (5) it gives access to students to be more active and participated in class activities.

The weakness of this material from the students point of view are only one, that is they sometimes hard to find internet connection. As most of the students are away from home and do not have their own internet connection, so sometimes they went to the nearest internet-cafe around their dorm to do the assignment.

\section{Suggestion}

An optimal education needs inovation and creativeness. Development of teaching learning material is one of the most important things to achieve thegoal of teaching and learning. With the existence of this research, a new teaching learning environment is invented and expected to full fill the students' need since it is provided with more appropriate material which can be used optimallyat University of Nusantara PGRI Kediri.

Some suggestion might be given for the lecturer who want to try a blended learning approach in their classroom, they can conduct the class in a modern environment, which is online through internet, without leaving the needs of the students in face-to-face traditional class. This material has very clear instruction which material that should be online and which one should be conducted in offline. So, it is very easy use. This product help them in supporting their teaching using blended learning approach.

For students this product offered new learning environment which is encourage their motivation in learning English autonomously. Especially in listening. The students also can be more active participant. They do not depend on their lecturer in the class only. They can do the exercise with their own pace in online virtual class. So, it is very fun activity and hopefully they would not feel bored in learning English.

The last, for further research, although some of the limitations is existed during the research process, this product may also taken into an experiment research to find out the effects of implementing this product in listening activity. It may inspire other researcher to completed the material with the same approach but in another way. 


\section{References}

Arabaz, P. \& Baker, M.B. (2003). Evolving Campus Support Models for ELearning Courses. Retrieved 13 December, 2014, fromhttp://www.educause.edu/ir/library/pdf/EKF/ekf0303.pdf

Arikunto, S.2002.Prosedur Penelitian: SuatuPendekatanPraktek, Ed. V. Cet.12.Jakarta:PTRienekaCipta

Bersin\& Associates. (2003). Blended learning: What works? An industry Study of The Strategy, Implementation, and Impact of Blended Learning. Oakland, CA: Bersin\& Associates.

Bonk, C.J., Olson,T., Wisher R.A., \&Orvis,K.L. (2002).Learning From Focus Group: An Examination of Blended Learning. Journal of Distance Education, 17 (3), 97-118.

Borg, W.R\& Gall,M.D.1983.EducationalResearch:An Introduction. (4thEd). White Plains: Longman, Inc.

Buck, G. 2001. Assessing Listening. Cambridge: Cambridge University Press.

Brown, G. 1987. Twenty-five Years of Teaching Listening Comprehension.English Teaching Forum 25, 4: 11-15.

Brown, H. Douglas. 2000. Principles of Language Teaching and Learning $4^{\text {th }}$ Edition. New York: Pearson.

Brown, H.Douglas. 2001. Teaching by Principles, an Interactive Approach to Language Pedagogy Second Edition. California: Longman.

Bonk, C. J., Kim, K. J., \& Zeng, T. (2006). Future directions of blended learning in higher education andworkplace learning settings. In E.-0. Baek (Ed.), The handbook of blended learning: Globalperspectives, local designs (pp. 550-567). San Francisco, CA: Pfeiffer

Brookfield, Stephen D. 1990. The Skillful Teacher: On Technique, Trust, and Responsiveness in the Classroom. San Franscisco: Jossey-Bass Inc.

Brown, Steve. 2006. Teaching Listening. Cambridge: Cambridge University Press

Flowerdew, John \& Miller, Lindsay. 2005. Second Language Listening; Theory and Practice. New York: Cambridge University Press.

Gardner, D., and Miller, L. (eds.). 1996. Tasks for Independent LanguageLearning. Alexandria: TESOL.

Goss, B. (1982). Listening as Information Processing. Communication Quarterly, 30,304-307.

Harmer, Jeremy. 2001. The Practice of English Language Teaching Third Edition. Cambridge: Longman.

Kavaliauskienè, Galina. 2011.Blended Learning in ESP Listening. English for Specific Purposes World, Issue 31 Volume 10.

Latief, Mohammad Adnan. 2013.Research Methods on Language Learning: An Introduction.-2nd Ed. Malang:UM Press 
Grgurović, Maja. 2011. Blended Learning in an ESL Class: A Case Study. CALICO Journal, volume 29 no.1.

Richards, J. C., and Rogers, T. S. 2001.Approaches and Methods in Language

Teaching: A Description and Analysis. Cambridge: CambridgeUniversity Press

Rost, M. 2002. Teaching and Researching Listening. London: Longman

Stroud,Casey.2010.Edmodo:A White PaperConnecting Technology and Curriculum . Rock Hill: Winthrop University

Susan Ko, Steve Rossen . 2001. Teaching online A Practical Guide. Boston: Houghton Miffin Company.

Suprijono. 2009. Cooperative learning: TeoridanAplikasi. retrieved from http://history22education.wordpress.com

Turner, K. 1995. Listening in a Foreign Language: a skill we take for granted. London: CILT.

Warschauer, Mark \& Healey,Deborah. (Eds).1998.Computers and Language Learning: An Overview. United Kingdom:Cambridge University Press. 